\begin{tabular}{|l|l|l||}
\hline \multicolumn{2}{|c|}{ PublisherInfo } \\
\hline \hline PublisherName & $:$ & BioMed Central \\
\hline \hline PublisherLocation & $:$ & London \\
\hline \hline PublisherImprintName & $:$ & BioMed Central \\
\hline \hline
\end{tabular}

\title{
HP1 dynamics
}

\begin{tabular}{|l|c|l||}
\hline \multicolumn{2}{|c|}{ ArticleInfo } \\
\hline \hline ArticleID & $:$ & 4690 \\
\hline \hline ArticleDOI & $:$ & $10.1186 /$ gb-spotlight-20030203-01 \\
\hline \hline ArticleCitationID & $:$ & spotlight-20030203-01 \\
\hline \hline ArticleSequenceNumber & $:$ & 42 \\
\hline \hline ArticleCategory & $:$ & Research news \\
\hline ArticleFirstPage & $:$ & 1 \\
\hline \hline ArticleLastPage & $:$ & 2 \\
\hline \hline & & RegistrationDate : 2003-2-3 \\
\hline ArticleHistory & $:$ & OnlineDate \\
\hline \hline ArticleCopyright & $:$ & BioMed Central Ltd2003-2-3 \\
\hline \hline ArticleGrants & $:$ & \\
\hline \hline ArticleContext & $:$ & 130594411 \\
\hline \hline
\end{tabular}




\section{Jonathan B Weitzman}

Email: jonathanweitzman@hotmail.com

Gene silencing can be achieved by packaging of genes into repressive heterochromatin domains. In the January 31 Science two papers describe the dynamics of mammalian heterochromatin and the associated heterochromatin protein 1 (HP1). Festenstein et al. generated transgenic mice that express a chimeric protein of HP1 $\beta$ fused to green fluorescent protein (GFP) in T lymphocytes (Science 2003, 299:719-721). HP1 $\beta$-GFP was seen in heterochromatic foci in T-cell nuclei. Using fluorescence recovery after photobleaching (FRAP) in living T cells, Festenstein et al. show that HP1 is highly mobile suggesting that heterochromatin maintenance is dynamic. HP1 mobility was increased upon T cell activation. In an accompanying paper Cheutin et al. describe a similar approach using GFP fusions of HP1- $\alpha,-\beta$ and $-\gamma$ in hamster cells (Science 2003, 299:721-725). The GFP-HP1- $\alpha$ and $-\beta$ forms were localized in larger heterochromatin domains. Experiments in fibroblasts from mice lacking the Suv39h histone methyltransferases demonstrated that HP1 mobility in heterochromatin is due to its binding to sites created by Suv39h. HP1 binding appears to correlate with global chromatin organization. Both the chromodomain and the chromoshadow domain are required for HP1 to bind to chromatin in vivo.

\section{References}

1. Heterochromatin: new possibilities for the inheritance of structure.

2. Science, [http://www.sciencemag.org]

3. The HP1 protein family: getting a grip on chromatin. 